\section{Nyretransplantasjon til eldre}

\author{
Nyretransplantasjon er et godt behandlingsalternativ for utvalgte eldre \\ pasienter med avansert nyresvikt. Nyrer kan doneres fra eldre avdøde.
}

Nyretransplantasjon regnes som det beste behandlingsalternativet for pasienter med avansert nyresvikt, men det finnes lite dokumenterte resultater fra transplantasjon hos eldre. Kristian Heldal har analysert epidemiologiske data fra nyretransplantasjoner som er utført i perioden 1990-2005, og konkluderer med at nyretransplantasjon er et godt alternativ for eldre pasienter.

- Eldre over 70 år har svært dårlig prognose ved dialyse. Våre data viser at nyretransplantasjon gir klart bedre overlevelse

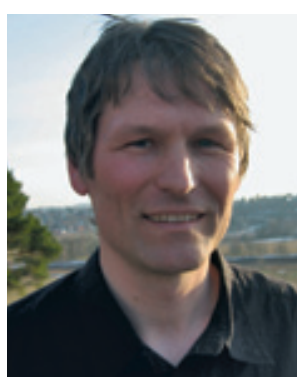
enn dialyse også for denne gruppen, og det er derfor et godt behandlingsalternativ for utvalgte pasienter over 70 år. Det er ingen grunn til å sette en øvre aldersgrense for Kristian Heldal. Foto privat må være klar over at behandling med dialyse over lang tid før transplantasjon gir dårligere resultater. Resultatene blir også bedre når akutte avstøtningsreaksjoner unngås. Dette er faktorer som det er mulig å kontrollere, sier Heldal.

Tilgang på organer er en begrensende faktor for transplantasjon. Bruk av nyrer fra avdøde, eldre pasienter gir generelt dårligere resultater. Men resultatene for den eldre pasientgruppen er akseptable.

- Mer utstrakt bruk av nyrer fra eldre personer som dør til eldre med nyresvikt kan gi eldre nyresviktpasienter et bedre behandlingstilbud, sier Heldal.

Han forsvarte avhandlingen Kidney transplantation in the elderly for ph.d.graden ved Universitetet i Oslo 28.5. 2010.

\section{Anne Forus}

anneforu@online.no

Tidsskriftet
Doktoravhandlinger

Se oversikt på side 1429

Tips oss om spennende

doktoravhandlinger

www.tidsskriftet.no/doktoravhandlinger

\section{Ordforklaringer}

Avansert nyresvikt: En tilstand der nyrene ikke lenger klarer å utføre sine oppgaver og pasienten får symptomer som skyldes opphopning av avfallsprodukter nyrene skal skille ut. Ved avansert nyresvikt kan det bli aktuelt å starte nyreerstattende behandling i form av dialyse eller transplantasjon. De hyppigste årsakene til avansert nyresvikt er høyt blodtrykk, diabetes samt immunologiske nyresykdommer (glomerulonefritt)

\section{Bevegelse bra mot svimmelhet}

\author{
Med ondt skal ondt fordrives. Svimmelhet kan best behandles \\ ved bevegelse som provoserer frem svimmelhet.
}

Det ser ut til at bevegelser fremmer sentrale kompenseringsmekanismer og derved reduserer svimmelheten, ifølge fysioterapeut Kjersti Thulin Wilhelmsen. I hennes doktorgradsstudier inngikk pasienter som hadde vært til utredning for langvarige svimmelhetsplager ved Balanselaboratoriet, Haukeland universitetssykehus. Hos majoriteten av pasientene hadde plagene en vestibulær årsak.

- De fleste pasientene hadde alvorlige plager med sin svimmelhet selv lang tid etter debut. Mange var i tillegg plaget med nakkeproblemer, og vi tror det har en sammenheng med at de over tid har vegret seg for å bevege hodet og kroppen fordi bevegelser fremkaller svimmelhet. Nakkemuskulaturen stivner og det er mulig at svimmelhet og nakkeproblemer gjensidig opprettholder hverandre, sier Wilhelmsen.

Hun har sett på hvordan en aktiv behandlingsform som fremmer kroppsbevissthet kombinert med bevegelser og øvelser som provoserer frem svimmelhet, kan hjelpe.

- Pasienter får dessverre ofte legeråd som «hvil deg, så blir du bedre». De bør heller få beskjeden «utfordre svimmelheten din, vær i bevegelse!». Pasienter som våger å bevege seg fra dag 1, selv om de kanskje blir kvalme, gjør trolig jobben selv. Men noen trenger hjelp til å bryte den onde sirkelen, og disse kan ha nytte av vestibulær rehabilitering hos fysioterapeut. Det er aldri for sent å begynne. Det er derfor et problem at man sjelden henviser til fysioterapi, sier Wilhelmsen.

Hun disputerte for ph.d.-graden ved Universitetet i Bergen 29.4. 2010 med avhandlong-lasting dizziness.

\section{Eline Feiring}

eline.feiring@legeforeningen.no

Tidsskriftet lingen Symptoms and signs in patients with

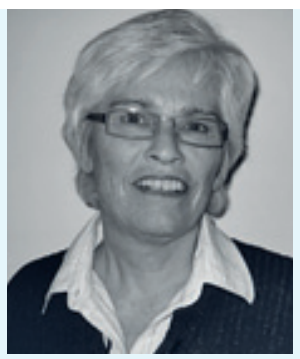

Kjersti Thulin Wilhelmsen. Foto privat

\section{Ordforklaringer}

Svimmelhet: Er en svært vanlig tilstand som oppstår ved et misforhold mellom systemer som opprettholder balanse (vestibularis, syn, propriosepsjon). Kan skyldes sykdommer/skader/forandringer i hvilket som helst av systemene. Svimmelhet kan også skyldes manglende evner til å bearbeide signaler og/eller initiere adekvate responser, og kan således representere et sentralt problem.

Vestibulær rehabilitering: Omfatter ulike tilnærminger som har til hensikt å fremme sentral kompensering, redusere opplevelsen av svimmelhet, bedre øye-hodebalanse og funksjonell balanse. Avhengig av pasientens hovedproblem benyttes svimmelhetsprovoserende øvelser, spesifikke øye-hode-bevegelser, osv. 